Please Note: This is an Accepted Manuscript of an article published by Taylor \& Francis in the Bulletin of Spanish Studies on 26 June 2019, available online: https://www.tandfonline.com/doi/full/10.1080/14753820.2019.1622876

It may contain errors and mistakes that were corrected in the published version.

\title{
The Virgin Embracing the Virgin: Eugenio Cajés' Short-Lived Iconography of Our Lady del Sagrario in Counter-Reformation Toledo
}

\author{
CLOE CAVERO DE CARONDELET
}

Ludwig-Maximilians-Universität München

In 1584, a new episode was inserted into the legend of the Descent of the Virgin to Toledo. The medieval version of this legend recounted that the Virgin had descended corporeally to the cathedral of Toledo in 665 to give a divine chasuble to the Visigothic archbishop of Toledo Saint Ildephonsus or Ildefonso (c. 607-667). ${ }^{1}$ According to the late sixteenth-century version, the Virgin had paused at the cathedral's altar on her way back to heaven and embraced the sculpture of Our Lady del Sagrario. ${ }^{2}$ A few decades later, this episode was translated into an image by the royal painter Eugenio Cajés

* I am grateful to Peter Cherry, Chiara Franceschini and Yonatan Glazer-Eytan, for their helpful comments and suggestions on the earlier drafts of this article. I also wish to thank Isabel García-Toraño for her expert advice on Eugenio Cajés' drawings. The research contributing to this article has received funding from the European Research Council (ERC) under the European Union's Horizon 2020 research and innovation programme (grant agreement No. 680192 / project SACRIMA, 'The Normativity of Sacred Images in Early Modern Europe', PI: Chiara Franceschini, LMU München). Previous work in preparation for this article was undertaken thanks to a 'Salvador de Madariaga' Fellowship at the European University Institute in Florence.

1 Juan Francisco Rivera Recio, San Ildefonso de Toledo: biografía, época y posteridad (Toledo: Estudio Teológico de San Ildefonso, 1985), 8-16, 230-33.

2 Alonso de Villegas, Flos Sanctorum: Segunda Parte y Historia General en que se escriue la vida de la Virgen (Toledo: Juan Rodríguez, 1584), 100. According to the paratextual information, the text was already finished in July 1583. I wish to thank Francisco Martínez Gutiérrez for his help in consulting this rare edition, which is preserved in the Biblioteca de Andalucía in Granada. References to Villega's text throughout will be given by folio number in parenthesis. 
(Madrid, 1574-1634) (Figure 1). ${ }^{3}$ Under heavenly circles of putti and soft clouds, which were features of Cajés' style praised by Jusepe Martínez, ${ }^{4}$ the lightly sketched image of Our Lady del Sagrario with the Christ Child seated on the altar occupies the centre of the sheet. Standing on a cloud over Ildefonso's empty episcopal throne at the right, the Virgin embraces her sculpted image with her right arm, while delicately caressing the figure of the Child with her left hand. Behind Mary are three virgin saints, holding their palms of martyrdom. Kneeling at the lower left of the scene is the archbishop Ildefonso, who holds his main work, De virginitate Sanctae Mariae, in his hands and appears to be reacting calmly to the divine apparition. A canon is kneeling beside him, and a sacristan holding a crozier and two angels are standing behind them. At the lower right and separated from the other figures by the throne, there is an old veiled lady holding a candle and a stick; she is witness to the miraculous event.

In this article, I will propose a new reading of this overlooked drawing by Eugenio Cajés and advance the argument that it presents an exceptional example of the short-lived iconography of the Virgin embracing Our Lady del Sagrario. Extensive archival research and fieldwork have not revealed any material or documentary evidence to indicate that a painting, print or sculpture with an analogous iconography was ever produced in early modern Spain. Therefore, Eugenio Cajés' drawing is the only known representation of this new episode of sacred history. Based on a complex meta-figurative challenge - that of the idea of the Virgin embracing one of her sculpted replicas, it constitutes a unique case for examining thesometimes conflictive-creation of sacred images after the Council of Trent.

After reconstructing the political context in which this episode of local history was fabricated, I will analyse how Cajés translated, modified and adapted the visual and textual sources into a two-dimensional image. By examining the contrasting meanings that Cajés' visual proposal for the Virgin embracing Our Lady del Sagrario conveyed, and by analysing the textual descriptions of this episode, this article will shed some light on the distinct reception of sacred images in Counter-Reformation Spain.

3 Madrid, Biblioteca Nacional de España (hereafter BNE), Dib/15/1/9: 280 x 189 mm. (within a sheet $297 \times 192 \mathrm{~mm}$.), red chalk and red wash on yellow laid paper. The larger sheet has been trimmed, and has pin-hole marks on its borders. The lower frame, where the name 'Eugenio Caxes' is inscribed in eighteenth-century handwriting, has been restored. See Ángel María Barcia y Pavón, Catálogo de la colección de dibujos originales de la Biblioteca Nacional (Madrid: Biblioteca Nacional de España, 1906), 26. Diego Angulo Íñiguez \& Alfonso E. Pérez Sánchez, A Corpus of Spanish Drawings, 4 vols (London: Harvey Miller, 1977), II, 18-19, No. 43. Gridley McKim-Smith, Spanish Baroque Drawings in North American Collections (Kansas: University of Kansas Museum of Art, 1974), 38.

4 Jusepe Martínez, Discursos practicables del nobilísimo arte de la pintura (Madrid: Manuel Tello, 1866), 115: 'Sus pinturas fueron muy amables y de grande union, y para significar glorias y nubes con tanta morbideza, que así antiguos como modernos, otro alguno no le ha pasado'. Though not published till the nineteenth century, Martínez' text was written $c .1675$. 


\section{The Reconsecration of Our Lady del Sagrario in the Late Sixteenth Century}

The corporeal Descent of the Virgin to present a divine garment to Saint Ildefonso was the main miracle of the Church of Toledo, Spain's primatial see. The earliest source for this miracle is the Vita vel gesta Sancti Ildefonsi, a medieval text that has been attributed to the obscure bishop Cixila. It explains the events that occurred on the morning of 18 December 665, the feast of the Expectation of the Virgin, when Ildefonso, preceded by a deacon and a clergyman holding a torch, opened the church doors to pray matins, and a strong heavenly light poured out. The canons fled, but Ildefonso, who knew what was happening, went towards the angelic choir and prostrated himself before the altar of the Virgin. There, he found the Virgin seated on his episcopal throne, surrounded by saintly virgins singing psalms. Ildefonso had passionately defended her virginity in his work $D e$ virginitate Sanctae Mariae, and she had come to reward him for his efforts, investing him with a divine garment to use in the Marian feasts. ${ }^{5}$ This story was represented as early as 1200 , and it became ubiquitous in the churches of the Spanish Peninsula, and especially within the Archbishopric of Toledo. ${ }^{6}$ However, this scene was also displayed in foreign sacred sites under Spanish patronage such as the church of San Giacomo degli Spagnoli in Rome and the Spanish chapel in the convent of Santo Spirito in Siena. ${ }^{7}$

Despite the fact that Toledo's cathedral did not have many relics relating to this episode, the Descent of the Virgin still became a fundamental miracle. According to medieval legends, the miraculous chasuble gifted by the Virgin and Ildefonso's bodily relics were sent to northern Spain to save them in the wake of the Moorish invasion. The chasuble was placed in the arca santa of Oviedo, where it still remains, and Ildefonso's bodily relic in the church of San Pedro in Zamora, where it was

5 Cixila's original Latin text is partially transcribed in: Juan Francisco Rivera Recio, 'La Catedral de Toledo, Museo de Historia. II', Boletín de La Real Academia de Bellas Artes y Ciencias Históricas de Toledo, 64-65 (1951), 24-80 (pp. 78-80). A partial Spanish translation also appeared in Juan Interián de Ayala, El Pintor christiano y erudito, ó Tratado de los errores que suelen cometerse frecuentemente en pintar y esculpir las imágenes sagradas, 2 vols (Madrid: Joaquín Ibarra, 1782), II, 84-85.

6 See especially the following for key resources on the paintings and sculptures of Saint Ildefonso, the majority of which can be found in Spain: Wifredo Rincón García \& Emilio Quintanilla Martínez, Iconografía de San Ildefonso, arzobispo de Toledo (Madrid: Real Cuerpo de la Nobleza de Madrid, 2005); Rosa López Torrijos, 'Iconografía de San Ildefonso desde sus orígenes hasta el siglo XVIII', Cuadernos de Arte e Iconografía, 1:2 (1988), 165-212; Rivera Recio, San Ildefonso de Toledo, 281-90.

7 Fernando Marías, 'Pintura, diplomacia y censura en la Cappella Paolina: desde Toledo y Madrid hasta Roma', in I rapporti tra Roma e Madrid nei secoli XVI e XVII: arte, diplomazia e politica, ed. Alessandra Anselmi (Rome: Gangemi, 2014), 58-86. The cathedral chapter of Toledo disputed Guido Reni's first version of the scene, where the angel was shown giving the chasuble to Ildefonso, and had it repainted by Giovanni Lanfranco. 
miraculously found in 1260. From the thirteenth century onward, and with renewed emphasis in the sixteenth and seventeenth centuries, the archbishops and canons of Toledo cathedral engaged in a prolonged litigation with Zamora to recover the body of Saint Ildefonso. Even though Pope Clement VIII ordered Ildefonso's bodily relic to be moved back to Toledo in 1594, the primatial see was only able to secure a finger relic of its patron saint decades later. ${ }^{8}$

As Tom Nickson and María Tausiet have recently demonstrated, the cathedral chapter found creative ways to maintain the memory of the Descent. The cathedral chapter encouraged devotion to the space where the Virgin had walked during her visit to Toledo. Later on, possibly around the fourteenth century, a cult developed around the white marble stone on which she had allegedly stepped. Sanctified by the Virgin's touch, this stone was placed in a separate chapel and venerated as a material testimony of the Descent. 9 The absence of Ildefonso's bodily relics was further compensated for by the cult of the Toledo patron saints Eugenio and Leocadia. Saint Ildefonso was Saint Eugenio's nephew, and therefore he played an integral part in Eugenio's vita and was usually present in his hagiographies. Moreover, as Ildefonso was the privileged witness to Saint Leocadia's miraculous apparition, they were frequently represented together on altarpieces throughout the Archbishopric of Toledo. ${ }^{10}$

The cathedral of Toledo's efforts to recover the body of its patron saint and the lost material evidence of the Virgin's Descent to Toledo were greatly intensified in the late sixteenth century. As is well known, Philip II appropriated relics from several Spanish dioceses and monasteries, in order to construct a relic collection that would symbolise the monarchical and spiritual identity of his kingdoms. ${ }^{11}$ Besides assembling this massive collection of relics in El Escorial, Philip II was also interested in restoring the prestige of his primatial see, Toledo. In 1565 and 1587, the king gave his support to the campaign for the bodily relics of Eugenio and Leocadia to be returned to the cathedral. At the time, the saints' relics were housed respectively in the churches of Saint Denis and Saint Ghislain. ${ }^{12}$ Moreover,

8 María Tausiet, El dedo robado: reliquias imaginarias en la España moderna (Madrid: Abada, 2013). Rivera Recio, San Ildefonso de Toledo, 3-16.

9 Tom Nickson, Toledo Cathedral: Building Histories in Medieval Castile (University Park, PA: Pennsylvania State University Press, 2015), 141-46.

10 María Tausiet, 'Trois saints en un: l'héritage légendaire de saint Ildefonse', in $L a$ cour céleste: la commémoration collective des saints au Moyen Âge et à l'époque moderne, ed. Olivier Marin \& Cécile Vincent-Cassy (Turnhout: Brepols, 2014), 185-98.

11 Guy Lazure, 'Possessing the Sacred: Monarchy and Identity in Philip II's Relic Collection at the Escorial', Renaissance Quarterly, 60:1 (2007), 58-93.

12 Jean-Marc Depluvrez, 'Les retours de Saint Eugène et Sainte Léocadie à Tolède en 1565 et 1587 (analyse de deux translations)', in Les Signes de Dieu aux XVIe et XVlle siècles, ed. Bernard Dompnier \& Genevieve Demerson (Clermont-Ferrand: Faculté des Lettres et Sciences humaines de l'Université Blaise Pascal, 1993), 113-32. For a recent study on the cult of Saint Leocadia in Toledo, see: Peter Cherry \& Arantza Mayo, 'The Fabric of Saintly 
Philip II proposed that the erudite scholar and Archdeacon of Toledo García de Loaysa y Girón (1534-1599) and his collaborators conduct scholarly research on the origins of Toledo. Editing a commented edition of Saint Ildefonso's works on the Virgin was one of their fundamental missions. ${ }^{13}$ Their interest in recovering and establishing the early origins of the see of Toledo was arguably fuelled by the rewriting of Catholic liturgy, history and hagiography that was being carried out, among others, by Cardinal Cesare Baronio. ${ }^{14}$ In Toledo and across Spain, groups of erudite ecclesiastics produced material and textual evidence of new histories that proved the prestigious early Christian-and thus pre-Muslim-origins of their dioceses and of their privileged relationship with the divine. ${ }^{15}$ In late sixteenth-century Spain, the dioceses were actively competing with each other as to which had the most prestigious Christian past.

The invention of the Virgin's embrace of Our Lady del Sagrario was the creative solution of the cathedral chapter of Toledo to revive devotion towards the miracle of the Descent and to boost the status of their church and the Archbishopric of Toledo in post-Tridentine Spain. The Virgin's decision to honour the Marian sculpture of Toledo with her touch provided the cathedral with new material evidence of the Descent, and downplayed the absence of Ildefonso's body and the chasuble while providing the cathedral with a privileged image of the Virgin. Following the Reconquest, and with increasing emphasis throughout the sixteenth century, sculpted images of the Virgin that had allegedly been hidden during the Moorish invasion began to miraculously appear all across Spain. They served as material testimonies to the early origins and long-standing veneration of the dioceses in which they appeared, while giving many of them additional

Proof: Leocadia of Toledo from Orrente to Calderón', Bulletin of Spanish Studies, 93:7-8 (2016), 1339-70.

13 Richard L. Kagan, Clio \& the Crown: The Politics of History in Medieval and Early Modern Spain (Baltimore: Johns Hopkins University Press, 2009), 257-58.

14 Katrina Olds, "The "False Chronicles", Cardinal Baronio, and Sacred History in Counter-Reformation Spain', The Catholic Historical Review, 100:1 (2014), 1-26. See also: Sacred History: Uses of the Christian Past in the Renaissance World, ed. Katherine E. Van Liere, Simon Ditchfield \& Howard Louthan (Oxford: Oxford University Press, 2012); Simon Ditchfield, Liturgy, Sanctity and History in Tridentine Italy: Pietro Maria Campi and the Preservation of the Particular (Cambridge: Cambridge University Press, 1995).

15 See, for example: Katrina Olds, Forging the Past: Invented Histories in CounterReformation Spain (New Haven: Yale University Press, 2015); Mercedes García-Arenal \& Fernando Rodríguez Mediano, The Orient in Spain: Converted Muslims, the Forged Lead Books of Granada, and the Rise of Orientalism, trans. Consuelo López-Morillas (Boston: Brill, 2013); Katherine E. Van Liere, 'Renaissance Chroniclers and the Apostolic Origins of Spanish Christianity', in Sacred History: Uses of the Christian Past in the Renaissance World, ed. Katherine E. Van Liere, Simon Ditchfield \& Howard Louthan (Oxford: Oxford University Press, 2012), 121-44; A. Katie Harris, From Muslim to Christian Granada: Inventing a City's Past in Early Modern Spain (Baltimore: Johns Hopkins University Press, 2007). 
status. ${ }^{16}$ As symbols of local identity and Catholic rule, the popularity of Marian images was boosted across Europe and the Americas. Secular and ecclesiastical institutions actively promoted their preferred images by printing books and leaflets that recorded their divine origins and miraculous actions, as well as by commissioning engravings and paintings and building shrines. ${ }^{17}$

One of the 'reactivated' images of Mary was the sculpture of Our Lady of Charity in Illescas, near Toledo. In 1562, popular devotion to this image was boosted after a disabled woman was miraculously healed. This phenomenon was just one of many similar miraculous events that occurred in the Archbishopric of Toledo during this period, and their profusion may have been viewed with particular unease by the cathedral chapter. As it happens, the sculpture of Our Lady of Charity was believed to have been owned by Ildefonso himself. ${ }^{18}$ In 1603, El Greco depicted this special connection in a canvas of Saint Ildefonso for the new church built in Illescas. There, the saint appeared to receive the divine inspiration to write his Marian book through the mediation of the image of Our Lady of Charity.

Faced with an ever more competitive landscape, the Church of Toledo felt that it ought to reaffirm its position as Spain's primatial see. Under the patronage of the Cardinal-archbishop Gaspar de Quiroga (r. 1577-1594), the transformation of the Sagrario image into a Marian relic was a brilliant strategy of image reconsecration. A learned ecclesiastic, Quiroga arrived in Toledo in 1577 with the task of reforming a diocese that had suffered as a

16 Felipe Pereda, Las imágenes de la discordia: política y poética de la imagen sagrada en la España del cuatrocientos (Madrid: Marcial Pons, 2007), 145-58; Honorario Velasco, 'Las leyendas de hallazgos y de apariciones de imágenes: un replanteamiento de la religiosidad popular como religiosidad local', in La religiosidad popular, II. Vida y muerte: la imaginación religiosa, ed. Carlos Álvaro Santaló, María Jesús Buxó i Rey \& Salvador Rodríguez Becerra (Barcelona: Anthropos, 1989), 401-10.

17 See Olivier Christin, Marie mondialisée: l' 'Atlas Marianus' de Wilhelm Gumppenberg et les topographies sacrées de l'époque moderne (Neuchâtel: Éditions AlphilPresses universitaires suisses, 2014); Jane Garnett \& Gervase Rosser, Spectacular Miracles: Transforming Images in Italy, from the Renaissance to the Present (London: Reaktion Books, 2013), 95-107; Megan Holmes, The Miraculous Image in Renaissance Florence (New Haven, CT: Yale University Press, 2013). For the Spanish case, see Françoise Crémoux, 'Las imágenes de devoción y sus usos: el culto a la Virgen de Guadalupe (1500-1750)', and Elena Sánchez de Madariaga, 'La Virgen de la Soledad: la difusión de un culto en el Madrid barroco', in La imagen religiosa en la monarquía hispánica: usos y espacios, ed. María Cruz de Carlos Varona, Pierre Civil, Felipe Pereda \& Cécile Vincent-Cassy (Madrid: Casa de Velázquez, 2008), 61-82 and 219-40; Jeffrey Albert Schrader, 'The Virgin of Atocha and Spanish Habsburg Devotion to Miraculous Images', Doctoral dissertation (New York University, 2003).

18 Gaspar de Jesús María, Manifiesto de la colu[m]na protectora de Israel en la Carpentania, y Sacro Paladion [...] la Villa de Yllescas [...] con la advocacion de la Caridad (Madrid: Manuel Ruiz de Murga, 1709), 268-71. 
vacant see for many long years. ${ }^{19}$ The cardinal's name and effigy were illustrated on the cover of the Flos Sanctorum: Segunda parte y Historia General en que se escrive la vida de la Virgen, which was written by Alonso de Villegas (1533-1603), a theologian and canon of the Mozarabic chapel of Toledo cathedral. ${ }^{20}$ In a section entitled 'La ymagen de la madre de Dios del Sagrario de la sancta yglesia de Toledo', Villegas presented the new episode in the following words:

La ymagen de nuestra Señora que esta sobre la segu[n]da puerta del Sagrario de la sancta yglesia de Toledo, es una de las mas insignes y venerables de España. [...] Hazela allende desto devotissima, q[ue] qua[n]do la sanctissima virgen [...] baxo a este sancto te[m]plo, y se sento en la cathedra do[n]de predicava el glorioso Sant Illefonso, y deffe[n]dia su pureza y virginidad, y desde alli le dio la vestidura q[ue] usasse en el sacrificio de la missa, al despartirse llego al altar mayor, y abraço a aquesta sancta imagen q[ue] en el estava: para que quedasse en su imagen testimonio y señal de la descension. [...] De todo esto se collige que ninguna ay en España de tanta devocion como ella, pues es un transumpto muy semejante al original, tocada despues de su glorioso cuerpo: levantada de los angeles: llena de milagros: puesta en la cabeça de la religion de España [...]. Y assi creo que ella es la mas viva ymagen de quantas en España oy ha labrado ningun ingenio humano [...]. (Flos Sanctorum, 100)

Villega's main achievement was perhaps to embed the new episode in a crucial void left in Cixila's narration of the Descent. The medieval author had written that Ildefonso prostrated himself ante Altare Sanctae Virginis, but had not elaborated further. Villegas artfully completed the legendary account, by establishing that the sculpture 'placed over the second door' of the cathedral's relic chapel-the sacrarium or sagrario-was the same sculpture before which Ildefonso had prayed. However, attention to this issue was not new. Prior to Villegas, medieval and early modern artists

19 See Henar Pizarro Llorente, Un gran patrón en la corte de Felipe II: Don Gaspar de Quiroga (Madrid: Universidad Pontificia de Comillas, 2004); Henar Pizarro Llorente, 'Gaspar de Quiroga y Pedro de Ribadeneyra: cronohistoria de una amistad', in Los jesuitas: religión, política y educación (siglos XVI-XVIII), ed. José Martínez Millán, Henar Pizarro Llorente \& Esther Jiménez Pablo, 3 vols (Madrid: Universidad Pontificia de Comillas, 2012), I, 123-54. On his suburban possessions in Toledo, see: Cloe Cavero de Carondelet, Una villa toledana del Quinientos: el cigarral del Cardenal Quiroga (Toledo: AUDEMA, 2014); Cloe Cavero de Carondelet, 'Entre Roma y Toledo: una iconografía compartida por Gregorio XIII y el cardenal Quiroga', in En tierra de confluencias: Italia y la Monarquía de España, siglos XVI-XVIII, ed. Cristina Bravo and Roberto Quirós (Valencia: Albatros, 2013), 257-72; Cloe Cavero de Carondelet, 'La decoración pictórica del cigarral del cardenal Quiroga', Anales de Historia del Arte, 23 (2013), 243-55.

20 On this portrait, see: Cloe Cavero de Carondelet, 'Las relaciones artísticas del cardenal Quiroga con Italia: un retrato veneciano en las colecciones del Museo del Prado', Boletín del Museo del Prado, XXXIV:52 (2016), 10-16. 
working from Cixila's narration had also had to deal with the representation of the Virgin's Descent before the Marian altar. A number of these images emphasised the idea that the miracle had been mediated by her sculpted image, as Ildefonso venerated it. We can see the tension between the representation of the Virgin and her replica in the miniatures that were used to illustrate two thirteenth-century manuscripts of the life of Saint Ildefonso. This is the case in the Parma Ildefonsus, which includes an image of Ildefonso praying before an ambiguous representation of the Virgin, which can be simultaneously read as a representation of Mary, of her statue, or even as a sculpted Virgin that came to life. ${ }^{21}$ By contrast, the author of the Madrid manuscript made an effort to distinguish between the hieratic and frontal sculpture placed on the altar (Figure 2) with that of the more dynamic and diagonal representation of the apparition of the Virgin (Figure 3). ${ }^{22}$ Later solutions on how to depict the Marian image before which Ildefonso had prostrated himself during the Descent seem to suggest the possibility of a conflation between the Virgin and her image on the altar. ${ }^{23}$ This distinction reminded the faithful of the importance of sacred images as mediators for the divine. ${ }^{24}$

The image that was chosen by Cardinal Quiroga and his collaborators to fill the gap in Cixila's text was the sculpture of the Virgin of Sagrario, a 114-cm Sedes Sapientiae image made from a wood core and dressed in a silver-gilt vestment with cabochons (Figure 4). Dated around 1200 and documented as being in the cathedral as early as 1257, it was believed to be the most ancient Marian sculpture of Toledo cathedral. ${ }^{25}$ The Renaissance cleric Blas Ortiz described the Sagrario as an image that was highly venerated, while the chronicler Pedro de Alcocer mentioned its miraculous powers and that it was the subject of widespread devotion. ${ }^{26}$ In 1571 , Our Lady del Sagrario was placed under the protection of a confraternity of

21 Parma, Biblioteca Palatina, Ms. Lat. 1650, De virginitate Sanctae Mariae (c. 1100), 9v: 'Saint Ildefonso praying to Mary'. This miniature is reproduced in Meyer Schapiro, The Parma Ildefonsus: A Romanesque Illuminated Manuscript from Cluny, and Related Works (New York: College Art Association of America, 1964).

22 Madrid, BNE, MSS/10087: Vida y obras de San Ildefonso, early thirteenth century, $8 \mathrm{v}$ and 110r. See also Schapiro, The Parma Ildefonsus, 64-66.

23 For example, see the depictions of the Virgin Giving the Chasuble to Saint Ildefonso by the Maestro de las Once mil vírgenes, c. 1490, tempera on panel, $165 \times 91 \mathrm{~cm}$., Museo del Prado, Madrid; Jerónimo Cosida, c. 1550-1590, oil on canvas, 75.2 x 56.4 cm., Pollok House, Glasgow Museums; and Hieronymus Wierix on the cover of Officia propria sanctorum Ecclesiae Toletanae (Antwerp: Balthasar \& Jan Moretus, 1616).

24 On the conflation between prototype and replica, see Victor Stoichita, El ojo místico: pintura y visión religiosa en el Siglo de Oro español (Madrid: Alianza, 1996), 57-62.

25 Nickson, Toledo Cathedral, 136-37.

26 La catedral de Toledo, 1549, según el Dr. Blas Ortiz: Descripción graphica y elegantissima de la S. Iglesia de Toledo, ed. Ramón Gonzálvez \& Felipe Pereda, transcripción del texto latino de Silvia Docampo, transcripción del texto español de Felipe Pereda (Toledo: Antonio Pareja, 1999), 196. Pedro Alcocer, Hystoria, o descripcion de la imperial cibdad de Toledo (Toledo: Juan Ferrer, 1554), 31v-32r. 
cathedral workers, but little is known of their activities. A printed image of the Sagrario, crowned and dressed, illustrates the frontispiece of the confraternity's constitutions. ${ }^{27}$ The fact that the image had no officially recognised miracles, ${ }^{28}$ and had no clear history was, however, advantageous for the promoters of the image, as it enabled them to build on existing devotion to it, and facilitated a fluid transition to the image's newer, more concrete status.

Alonso de Villegas anchored the new episode in a learned analysis of the documentary and material sources that proved its authenticity. He began by stating that he had relied on an account authored by García de Loaysa, one of Quiroga's closest and most learned colleagues in the cathedral chapter of Toledo. Loaysa had a promising career: he was appointed as an instructor to Prince Philip (later Philip III) in 1585; in 1595, he was made governor of the archbishopric; and in 1598, he became the archbishop of Toledo and was simultaneously shortlisted for the cardinal's hat. His scholarly expertise, authority and close connections with members of the royal court made him a fundamental figure in the application of the Tridentine requirements in Spain. ${ }^{29}$ His prestige as a scholar likewise automatically validated the ancient texts he had allegedly found in the cathedral's archive. Villegas complemented the authority of Loaysa's findings with a complete account of the origins and history of the Sagrario image, establishing that it was a man-made image that '[d]el aspecto y forma y vestido que tiene y talla se entiende ser obra de los Godos' (Flos Sanctorum, 100). Following the narrative of miraculous rediscovery of images endemic in the sixteenth century, Villegas explained that during the Moorish invasion the clergy had hidden the Sagrario in an underground well beneath the altar. Since then, he claimed, angels had carried it in a procession through the cathedral every night. After the Reconquest, a divine light miraculously showed the clergy where the image was hidden. Thus, Villegas' narration simultaneously reminded his readership of the pre-Muslim origins of the image and of Toledo's long-standing devotion to the Virgin.

27 Toledo, Archivo Municipal, Constituciones de la Hermandad de Nuestra Señora del Sagrario y Señor San Eugenio (Toledo, 1571).

28 William A. Christian, Jr. misguidedly indicated that the people of Toledo believed that the Sagrario was responsible for healing Prince Don Carlos in 1562, as he based his assertion on a largely inaccurate elaboration of the recently discovered original manuscript of the second part of Francisco de Pisa's description of Toledo: William A. Christian, Jr., Local Religion in Sixteenth-Century Spain (Princeton: Princeton University Press, 1981), 157. See note 41 for further clarification on Francisco de Pisa's text.

29 However, his ecclesiastical activities are still awaiting an in-depth study. Until then, see Ricardo Sáez, 'Contribution à l'historie religieuse de l'Espagne: étude introductive à l'édition du synode tenu à Tolède en 1596, sous la présidence de García de Loaysa, gouverneur de l'archevêché', Melanges de La Casa de Velázquez, 22 (1986), 223-68 (pp. 23239). 
The new episode of the Virgin embracing Our Lady del Sagrario emphasised the fundamental role of holy images in early modern Catholicism. Alonso de Villegas and the Church of Toledo had shifted the centre of devotion of the Descent from the stone relic that allegedly bore the imprint of the Virgin's feet to the Marian sculpture she had so warmly embraced. In so doing, the cathedral displayed its special relationship with the Virgin while reasserting the fundamental importance of images for veneration. As is well known, the Christian theory of images was largely grounded in a belief in images that had divine origins, such as the acheiropoieta and the portraits of Christ and the Virgin Mary made by saints. ${ }^{30}$ The Tridentine emphasis on this idea compelled the dioceses to create legends of the miraculous apparitions and discoveries of their most venerated images. ${ }^{31}$ Villegas had indicated that Our Lady del Sagrario was 'a reflection very close to the original', which made it the most privileged, human-made portrait of the Virgin in Spain (Flos Sanctorum, 100). Human-made but divinely touched, the Sagrario consequently had a lower prestige than the acheiropoieta but a higher one than all the images whose power was grounded solely in their miraculous rediscovery.

The new status of Our Lady del Sagrario was celebrated in 1584 when a new piece was commissioned for the statue's crown. The commission was given to the silversmith Alejo de Montoya, who finished it in 1586. The new addition was intended to be attached to the mid-sixteenth-century tiara, and was made of gold and silver, and decorated with pearls, diamonds, rubies, emeralds and other precious stones. ${ }^{32}$ This lavish piece, which was taken from the cathedral in 1869 (or 1879) and is now lost, is identified with the crown represented in early seventeenth-century, half-length paintings of the Virgin del Sagrario, such as one in Toledo cathedral (Figure 5). ${ }^{33} \mathrm{~A}$ possible reference to the reconsecration of the Sagrario may be seen in the impressive golden crown worn by Mary in the painting of the Virgin Giving the Chasuble to Saint Ildefonso, with Saint John Evangelist preserved in the Museo de Santa Cruz in Toledo (Figure 6). The painting is attributed-with some discussion—to Diego de Aguilar the Younger (c.

30 A fundamental work in this area of study is Hans Belting, Likeness and Presence: A History of the Image before the Era of Art (Chicago: University of Chicago Press, 1994); here see especially 47-77.

31 Javier Portús, Metapintura: un viaje a la idea del arte en España (Madrid: Museo Nacional del Prado, 2016), 27-28.

32 See Francisco J. Sánchez Cantón, 'La corona de la Virgen del Sagrario de la Catedral de Toledo', Archivo Español de Arte y Arqueología, 4:12 (1928), 245-46; Manuel R. Zarco del Valle, Datos documentales inéditos para la historia del arte español, II: Documentos de la catedral de Toledo, 2 vols (Madrid: Imprenta Clásica Española, 1916), II, 238-39.

33 Elías Tormo, 'A Toledo, por las tardes: el Museo Catedralicio. Notas para viajes en auto', Boletín de la Real Academia de la Historia, 99:2 (1931): 415-58 (p. 428). See also Luis Moreno Nieto, Santuarios marianos de Castilla La Mancha (Madrid: Ediciones Encuentro, 1995), 313-14. 
1558-1624), who in 1580 was working for the cathedral. ${ }^{34}$ Although the ornamentation and general proportions of the two crowns are different, the painter's emphasis on this element seems to be a reference to the new crown commissioned for the Sagrario. It is, therefore, tempting to suggest that the painting attributed to Aguilar was an early visual elaboration of Our Lady del Sagrario's new privileged status.

The divine favour that Saint Ildefonso received, but for which the church had no relics, was thus transformed into a more collective experience by merging the wooden sculpture of the Sagrario with Cixila's description of the Descent. According to this new version, the Virgin had not only descended to the cathedral to favour its archbishop but also to honour the Marian image venerated by the people of Toledo. The late sixteenth-century transformation of Ildefonso's individual experience into a collective vision is also present in El Greco's Vista y Plano de Toledo (Museo del Greco, Toledo), which has been dated around 1610-1614. This painting is the only known image of the Descent in which Ildefonso has been completely erased from the miracle itself, in pursuit of a symbolic representation of the Virgin's favour to the city of Toledo.

\section{Eugenio Cajés and the Creation of a New Iconography}

The process through which Eugenio Cajés arrived at the composition represented in his drawing reflected the challenges intrinsic to the creation of a new iconography involving direct contact between the Virgin and her replica. Since the eighteenth century, when the ink inscription 'Eugenio Caxes' was added to the lower part of the sheet, this drawing has been unanimously attributed to the royal painter. Born in Madrid, the son of the Tuscan royal painter Patricio Cajés and a Spanish woman, Eugenio Cajés learned the art of painting in El Escorial and Rome, the city where he appears to have spent some years in his youth. Documented as being back in Madrid in 1598, he was later appointed pintor del rey in 1612, an office that he augmented with commissions for many works from aristocratic and ecclesiastical patrons. ${ }^{35}$ He was well integrated into the literary and artistic

34 This painting has been also attributed to Juan Sánchez Cotán. See $A$ imagen y semejanza: 1700 años de santidad en la Archidiócesis de Toledo, ed. Pilar Gordillo Isaza \& Augusto Antolínez (Toledo: Arzobispado de Toledo, 2004), 155. Isabel Mateo Gómez \& Amelia López-Yarto, Pintura toledana de la segunda mitad del siglo XVI (Madrid: Consejo Superior de Investigaciones Científicas, 2003), 31-36. Diego Angulo Íñiguez \& Alfonso E. Pérez Sánchez, Historia de la pintura española: escuela toledana de la primera mitad del siglo XVII (Madrid: Instituto Diego Velázquez, 1972), 19.

35 This painter is still awaiting a comprehensive monograph. The reference studies remain Diego Angulo Íñiguez \& Alfonso E. Pérez Sánchez, Historia de la pintura española: escuela madrileña del primer tercio del siglo XVII (Madrid: Instituto Diego Velázquez, 1969), 212-59; Magdalena de Lapuerta Montoya, Los pintores de la Corte de Felipe III: la Casa Real de El Pardo (Madrid: Fundación Cajamadrid, 2002), 305-25; Benito Navarrete Prieto, 'I segni nel tempo': dibujos españoles de los Uffizi. Catálogo de la exposición celebrada en la 
circles of the court of Madrid. He was a friend of Lope de Vega and a close collaborator as well as a great friend of the well-known painter and art theoretician Vicente Carducho. Cajés and Carducho shared many commissions and participated together in a lawsuit for a tax exemption that was based on the recognition of the higher status of the art of painting. ${ }^{36}$ Between 1614 and 1615, the two painters carried out the lavish pictorial decoration of the new Sagrario chapel in Toledo cathedral. As will be argued in what follows, the establishment of a relationship of patronage between Cardinal Sandoval and his court with Cajés would be fundamental in the creation of this drawing.

Here identified as The Virgin Embracing Our Lady del Sagrario, the drawing was Eugenio Cajés' proposal for visualising the new episode of Toledo's sacred history, which had initially been published in Alonso de Villegas' Flos Sanctorum: Segunda Parte. The drawing, however, remains no more than the painter's proposition for making visible what had previously been invisible to the eyes, for no archival or material evidence indicates that it was ever translated into a painting. The high level of elaboration in Eugenio Cajés' red chalk composition and the fine line framing of the drawing indicates that it was probably conceived as a presentation design. The artist has portrayed divine light emanating from the effigy of Our Lady del Sagrario, and has bathed the witnesses to the miracle in a red wash. With a darker shade of red chalk, Cajés has contoured the Virgin's body and outlined the main facial features of some of the characters. This drawing has a similar level of detail to the painter's Annunciation and Presentation in the Temple held by the Philadelphia Museum of Art, which are also preparatory drawings made for unknown locations. ${ }^{37}$ It is possible that Cajés worked in collaboration with a hitherto unidentified patron, and combined a variety of textual sources and visual models for creating the image of the new sacred scene of the Sagrario. The identification of these sources suggests that the drawing was sketched after 1616 and probably around 1620, thus soon after the new Sagrario chapel was unveiled.

By the turn of the seventeenth century, the Virgin's embrace had been replicated and elaborated on in many religious texts and chorographic

Real Academia de Bellas Artes de San Fernando, del 12 de mayo de 2016 al 24 de julio de 2016 (Madrid: Fundación Mapfre, 2016), 137-51.

36 The most recent studies on Vicente Carducho are: Laura R. Bass \& Jean Andrews. 'Me Juzgo Por Natural de Madrid: Vincencio Carducho, Theorist and Painter of Spain's Court Capital', Bulletin of Spanish Studies, 93:7-8 (2016), 1301-37, and On Art and Painting: Vicente Carducho and Baroque Spain, ed. Jean Andrews, Jeremy Roe \& Oliver Noble Wood (Cardiff: University of Wales Press, 2016).

37 Angulo Íñiguez \& Pérez Sánchez, A Corpus, II, 14-15, Nos. 6 and 17. Both drawings are pen and sepia wash over black chalk. 
volumes. ${ }^{38}$ Moreover, Villegas's Flos Sanctorum: Segunda Parte had undergone multiple editions both in Spain and beyond. ${ }^{39}$ Over the following decade, numerous printed volumes would further confirm the episode's success. ${ }^{40}$ Some authors, however, were quite sceptical about the veracity of this new episode and openly argued against it in their works. Francisco de Pisa criticized the texts that stated that the Virgin had remained for a longer period in the cathedral after giving the chasuble to Ildefonso, whether it was to attend a mass, for processing through the church or "en otras particularidades, que ni tienen fundamento ni se hallan escritas en autor alguno de los antiguos'. ${ }^{41}$ In response to these critiques, favourable scholars provided additional evidence for the embrace of the Sagrario. In his Libro de la Descension de Nuestra Señora the Jesuit Francisco Portocarrero referred to one of the false chronicles (also known as cronicones) that had been released in 1594 by a fellow Jesuit Jerónimo Román de la Higuera. These chronicles provided detailed evidence of the origins and unbroken development of Christianity in Spain until the twelfth century, thus bridging controversial junctures such as the Muslim

38 See Toledo, Biblioteca de Castilla-La Mancha, Borbón-Lorenzana, Ms. 198; Juan Bravo de Acuña, Libro de la fundacion de la sancta yglesia de Toledo, sus grandeças, primaçia, dotaçiones y memorias, en 1604 (1746), 18r; Francisco Pereda, Historia de la Santa y Devotissima Imagen de Nuestra Señora de Atocha, Patrona de Madrid (Valladolid: Sebastian de Cañas, 1604), 236v-40v; Francisco Portocarrero, Libro de la Descension de Nuestra Señora a la Santa Yglesia de Toledo (Madrid: Luis Sánchez, 1616), 43-44, 84-96; Pedro de Herrera, Descripción de la Capilla de Nuestra Señora del Sagrario (Madrid: Luis Sánchez, 1617), 14-17v; Pedro Salazar de Mendoza, El Glorioso Doctor San Il[d]efonso, Arzobispo de Toledo (Toledo: Diego Rodríguez, 1618), 145-49.

39 See also Axelle Guillausseau, 'Des hagiographies collectives au service de l'universalisme tridentin? Réflexions sur les trajectoires éditoriales des Flos sanctorum d'Alonso de Villegas et de Pedro de Ribadeneyra', in La cour céleste: la commémoration collective des saints au Moyen Âge et à l'époque moderne, ed. Olivier Marin \& Cécile VincentCassy (Turnhout: Brepols, 2014), 119-30; José Aragüés Aldaz, 'Tendencias y realizaciones en el campo de la hagiografía en España (con algunos datos para el estudio de los legendarios hispánicos)', in Memoria Ecclesiae, XXIV (2004), 441-560 (pp. 514-15). An early translation of Villegas' Segunda Parte as Nuouo leggendario della vita di Maria Vergine immacolata madre di Dio was published in 1595 in Venice by Giovanni Battista Ciotti.

40 Besides the inclusion of the episode of the Virgin's embrace in hagiographies and local histories such as those mentioned in the two foregoing footnotes, there were also independent pamphlets dedicated to Our Lady del Sagrario including those by Luis Hurtado, Imagen del Sacro-Erario de la Santa Iglesia de Toledo, Primada de las Españas: en brazos de su original Maria Santissima (Toledo: Francisco Calvo, 1655).

41 Francisco José Aranda Pérez, Toledo circa 1605: la Historia-Descripción Cristianopolitana de Francisco de Pisa (Toledo: Antonio Pareja Editor, forthcoming), 254. I wish to thank Francisco José Aranda for generously providing me with a copy of this study. It includes a transcription of Pisa's manuscript that supercedes the previous, inaccurate transcription in Apuntamientos para la II parte de la 'Descripción de la Imperial Ciudad de Toledo' según la copia manuscrita de don Francisco de Santiago Palomares, con notas originales autógrafas del Cardenal Lorenzana, estudio preliminar, transcripción y notas de José Gómez-Menor (Toledo: Instituto Provincial de Investigaciones y Estudios Toledanos, 1976). 
occupation of the Iberian Peninsula. Most conveniently, the document attributed to Higuera's fictional author Julián Pérez proved the authenticity of the Virgin's embrace of the Sagrario by stating that it was known through 'tradition'. ${ }^{42}$ Portocarrero probably hoped that the learned reader would identify Julián Pérez's text with the written source that García de Loaysa had allegedly seen in the cathedral archives, without, however, establishing this precise connection.

Moreover, the drawing also evinces Cajés' deep knowledge of the ongoing discussions on the details of the Descent of the Virgin that were taking place in Toledo at the time. Amongst the many texts that the painter surely read is the concise description by Francisco Pereda in his Historia de Nuestra Señora de Atocha, which seems to be a particularly accurate source for the painter's composition..$^{43}$ In the majority of the texts, the narration of the embrace was contained in the sections devoted to Mary, and not in those dealing with the life of Ildefonso. Pereda's early elaboration of Villegas' text instead had the distinctive feature of unifying the accounts of the Virgin's embrace and of the giving of the chasuble, while also referring to all the material proofs of the miracle. In unifying these two episodes, Pereda provided the reader with a more cohesive image of the different stages of the Descent, while also hinting at Ildefonso's presence in the Virgin's embrace.

Eugenio Cajés constructed this unprecedented iconography by relying on the well-known iconography of the Virgin giving the chasuble to Saint Ildefonso and on the representation of the material relics in this miracle. By providing the viewer with a recognisable composition and familiar figures, Cajés created an image that could be easily read by both learned and unlearned viewers. In this sense, Cajés consciously departed from Carlo Saraceni's innovative depiction (Figure 7), which was one of the six canvases that arrived from Rome in 1614 for the Sagrario chapel's oratories. Although Saraceni's paintings received uneven critiques on their arrival in Toledo due to the figures' size and lack of proportion, this particular canvas appears to have been quite successful. ${ }^{44}$ Saraceni's

42 'Assi lo dice el Arcipreste Julian Perez: (...) La imagen de la bienaventurada Virgen Maria, que se guardò en tiempo de los moros, y aora es muy estimada, estava en tiempo de San Il[d] efonso en el altar mayor, y es tradicion que despues de aver dado Nuestra Señora la casulla a san $\mathrm{Il}[\mathrm{d}]$ efonso, quando se apartò del, la abraçò, y desde entonces San $\mathrm{Il}[\mathrm{d}]$ efonso la tuvo mayor devocion, y los Reyes de España la veneran con particular reverencia' (Portocarrero, Libro de la Descension, 85v-86). On Román de la Higuera and the cronicones, see: Olds, Forging the Past.

43 Pereda, Historia de la Santa y Devotissima Imagen, 237-40.

44 See Fernando Marías, 'Carlo Saraceni e la Spagna', in Carlo Saraceni, 1579-1620: un veneziano tra Roma e l'Europa, ed. Maria Giulia Aurigemma (Rome: De Luca, 2013), 4555, 254-56. Cajés' composition might be one of the earliest adaptations of Saraceni's model, together with Pedro Orrente's altarpiece of Villarejo de Salvanés, dated around 1616-1617. Enrique Lafuente Ferarri, 'Pedro Orrente y el perdido retablo de Villarejo de Salvanés', 
rendition of the miracle placed unprecedented emphasis on heavenly glory, which diminished the traditional representation of the church's interior. He depicted the Virgin standing, which was a relatively unusual format in paintings, though quite common in early Renaissance reliefs and sculptures. In Eugenio Cajés' drawing, the Virgin also appears standing upon a soft cloud, surrounded by a heavenly glory and leaning toward the image of Our Lady, in a similar gesture to that generally used to depict her presentation of the chasuble to Ildefonso.

Nevertheless, in his representation of the material evidence of the miracle, Cajés' design for the Virgin embracing Our Lady del Sagrario diverged from Saraceni's canvas and from most paintings of the giving of the chasuble. In his careful representation of the Virgin's altarpiece, Ildefonso's episcopal throne and the stone footstool where the Virgin had placed her feet, Cajés followed the prints that illustrated Portocarrero's Libro de la Descension and Pedro Salazar de Mendoza's El Glorioso Doctor San Il[d]efonso. In the first, Pedro Angelo, a Toledan engraver, represented Ildefonso's arrival at the cathedral, surrounded by the frightened clergy, simultaneously with the scene of the chasuble (Figure 8). He sets the scene in contemporary Toledo, which is clearly recognisable, as references to Cardinal Sandoval's patronage are visible in the model of the new Sagrario chapel and the new façade of his palace. The Sagrario image is placed on the altar, adorned with a crown and textile garments. Although this wooden sculpture was perpetually dressed in silver clothing, her display without textile clothing was deemed indecent and not inspiring of devotion, and was thus strictly regulated by the cathedral chapter. ${ }^{45}$ In the print included in Salazar de Mendoza's volume, engraved by Alardo de Popma after Antón Pizarro, the minute representation of the stone footstool is complemented by explanatory inscriptions. An analogous attention to material details was also present in a now destroyed drawing from the first half of the seventeenth century that has been attributed to Angelo Nardi. In it, the scene was inserted within a church interior decorated with a large retablo including Our Lady del Sagrario. ${ }^{46}$ Cajés' drawing remains a notable exception since most seventeenth-century painters privileged the depiction of huge heavenly glories over the incorporation of the contact

Archivo Español de Arte, 14:48 (1941), 503-16. Thought to be lost during the Spanish Civil War, the painting is now preserved at the cigarral of the Ángel Custodio in Toledo.

45 Toledo, Archivo Capitular, Libro de Actas Capitulares 27, 59v: 22 August 1615. On the restrictions surrounding the adornment of images, see: Susan Verdi Webster, 'Shameless Beauty and Worldly Splendor of the Spanish Practice of Adorning the Virgin', in The Miraculous Image in the Late Middle Ages and Renaissance, ed. Erik Thunø \& Gerhard Wolf (Rome: 'L'Erma' di Bretschneider, 2004), 249-71.

46 Angulo Íñiguez \& Pérez Sánchez, A Corpus, II, 54, No. 290. This drawing, formerly in the Instituto Jovellanos of Gijón, was destroyed in 1936. Also see a 1694 print by Gregorio Fosman in Antonio Bonet, Estampas: cinco siglos de imagen impresa (Madrid: Ministerio de Cultura, 1982), 56, No. 35. 
relics of the miracle. This divergence speaks to Eugenio Cajés' need to weave this new episode into the existing evidence of the Descent.

The episode of the Virgin embracing the Sagrario transformed what had until then primarily been shown as Ildefonso's individual experience into a collective vision and an exaltation of the Church of Toledo. This transformation is most evident in Cajés' drawing, where Ildefonso did not appear as the predominant witness and was not placed in a privileged position. The lack of clarity in the representation of Ildefonso's main attribute, the prodigious garment gifted by the Virgin, further complicates his identification for the viewer. In fact, neither Ángel Barcia nor Diego Angulo and Alfonso E. Pérez Sánchez identified the saint as one of the two kneeling ecclesiastics in their studies. According to my alternative reading of this scene, however, the presence of the Toledan saint, as a fundamental witness to the Virgin's Descent, is imperative. I argue that the kneeling cleric holding a book in his hands, wearing what seems to be an unornamented cope over his shoulders must be identified with Ildefonso. As we have seen above in Pedro Angelo's print, the representation of the Toledan archbishop reacting calmly to the miracle with his book $D e$ virginitate was a conventional way of visualising Cixila's text.

Though not erroneous, Cajés' representation of Ildefonso's divine garment did not conform to normative visual standards. Instead of depicting it as a chasuble, the painter represented a long cope-a liturgical vestment, similar to a long mantle or cloak-resting heavily upon the saint's shoulders. This unusual representation of the garment might be seen as a learned choice amongst the alternative theories on the material nature of this divine textile relic. It is possible to find conflicting descriptions of the prodigious garment in other medieval and early modern sources, which referred to it as a chasuble, a cape and an alb. In a letter addressed to Portocarrero in 1598, the Jesuit father Sebastián Sarmiento explained that it ought to be 'un zendal de color de zielo en forma de capuz portugués'. ${ }^{47}$ In turn, Francisco de Pisa argued that it was 'un capuz cerrado y ancho que rodeaba todo el cuerpo' in the style of medieval episcopal garments. ${ }^{48}$ By the turn of the seventeenth century, however, prevailing opinion argued that it was a chasuble. The canon Pedro Salazar de Mendoza argued that artists had represented chasubles in all the painted and sculpted images of the miracle, including the coat of arms of Toledo cathedral. Therefore, the open cape was probably Eugenio Cajés' alternative solution to reconcile the requirements of the drawing's learned patron. In fact, the painter represented normative episcopal chasubles in

47 Tausiet, El dedo robado, 123-89 (pp. 174-89); see also María Tausiet, 'The Prodigious Garment: A Relic Becomes Real in Early Modern Spain', in Dying, Death and Burial in Reformation Europe, ed. Elizabeth C. Tingle (Burlington: Ashgate, 2015), 197-215 (pp. 214-15).

48 Aranda Pérez, Toledo circa 1605, 258. 
his two paintings of the giving of the chasuble, which are now preserved in the Museo del Prado in Madrid and the Musée des Beaux-Arts in Bordeaux. ${ }^{49}$

Cajés' drawing symbolises the collective character of the miracle by including Ildefonso and three witnesses on either side of the central scene, each of whom experienced the divine in different ways. On the left are Ildefonso, a canon and a sacristan holding a crozier. The latter two were mentioned in Cixila's text and were found in many fifteenth- and sixteenthcentury representations. Cajés seems to have envisaged the two kneeling figures in a similar way as had his friend Carducho in The Virgin Mary and Saint Peter Appearing to the First Carthusians (Museo del Prado, Madrid)-which is a well-known representation of a collective vision. ${ }^{50} \mathrm{On}$ the right side of Cajés' drawing, we can see the fourth witness, an old lady holding a candle and a stick, who is obscured from the other figures by the episcopal seat. It has been argued that the addition of the old lady as a witness in sixteenth- and seventeenth-century representations of the Descent was connected to the inclusion of an analogous character in theatrical plays of the Descent during the late sixteenth century. ${ }^{51}$ In this case, her inclusion seems to point towards the influence of the Auto de la Descensión, which was written by the canon José de Valdivielso, Cardinal Sandoval's chaplain, in 1616. The author described an old lady who had fallen asleep in a corner of the chapel after venerating Our Lady del Sagrario and who, from her privileged position, was able to witness both the presentation of the chasuble to Saint Ildefonso and the Virgin's embrace..$^{52}$ In addition, the presence of the old lady may have been used to highlight the idea that the clergy and the people of Toledo collectively experienced the Virgin's Descent, and thereby downplayed any possible interpretation that the scene represented Ildefonso's individual experience.

Besides the creation of a new iconography, Eugenio Cajés was challenged to envisage an unprecedented idea. He was required to represent the relationship between the divine prototype of Mary and a specific sculpted replica that was created by 'human genius'. This leads us to an essential tension in early modern theory of sacred images, where normative guidelines established that sacred images were to be venerated for what they represented, yet they coexisted alongside a widespread devotion towards actively miraculous images. Cases of human-made images

49 See Angulo Íñiguez \& Pérez Sánchez, Historia de la pintura española: escuela madrileña del primer tercio del siglo XVII, 247-48, Nos. 171 and 172.

50 Stoichita, El ojo mistico, 90-91.

51 López Torrijos, 'Iconografía de San Ildefonso', 165-212; Rincón García \& Quintanilla Martínez, Iconografía de San Ildefonso, 203-14.

52 Madrid, BNE, RES/80: José de Valdivielso, Auto famoso de la descensión de Nuestra Señora en la Santa Iglesia de Toledo, 1643. See also José de Valdivielso, Auto famoso de la descensión de Nuestra Señora en la Santa Iglesia de Toledo: BN Madrid, Ms. Res. 80, ed. Joseph Thomas Snow (Exeter: University Press, 1983). 
that were subject to such a privileged relationship with the Virgin were rare, and representations of the Virgin, Christ or saints together with sacred images were scarce. In the limited number of cases that have survived, they tend to be represented in a generic way and only seldom were they associated with specific cult images. In the well-known cases of Saint Luke painting the Virgin and Saint Dominic in Soriano, painters rarely represented a recognisable icon. Still, there are some exceptions, such as Juan Correa's Saint Luke Painting the Salus Populi Romani or Gaspar de la Huerta's painting of angels sculpting Our Lady of the Desamparados of Valencia. ${ }^{53}$ Alternative examples of images that were in contact with the divine can be found in paintings representing individual visionary experiences, which were often facilitated by images and objects. Paintings such as Francisco Ribalta's Christ Embracing Saint Bernard and Alonso Cano's Lactatio Bernardi evinced the ambiguous relationship between the representation of (unspecified) works of art and divine visions in seventeenth-century Spanish art. 54

Through the representation of a sacred image in contact with its prototype, Cajés' drawing also engages with the debates on metapainting in early modern art. In a concise definition, Lorenzo Pericolo defines metapainting as the 'self-staging of painting within a painting'. One of the pictorial devices through which painters staged this fictiveness was by incorporating a painting, or an image of equivalent status, as an object of representation within the painting itself. ${ }^{55}$ This is the case with what Victor Stoichita denominates the inset image, a painted icon inserted into a pictorial context through transposition. ${ }^{56}$ Cajés incorporates the representation of a human-made Marian image into a scene of Marian apparition. In so doing, he advocates for the crucial role of sacred images in Catholicism in a twofold, complementary but somehow contradictory, way. On the one hand, the presence of the divine model underscores the materiality and fictiveness of sacred images, and evokes their incapability of substituting the prototype. On the other hand, the pictorial representation of the Virgin's embrace of a human-made Marian sculpture speaks to the great prestige of sacred images and their makers, thus emphasising the divine prestige of art and artists. All in all, this drawing reveals the exceptional power of Our Lady del Sagrario, as simultaneously being a passive recipient of divine favour and an active image mediator of the divine.

53 These and other similar images are analysed in Portús, Metapintura, 19-82.

54 Stoichita, El ojo místico, 113-49.

55 Lorenzo Pericolo, 'What is Metapainting? The Self-Aware Image Twenty Years Later', in Victor Stoichita, The Self-Aware Image: An Insight into Early Modern MetaPainting, trans. Anne-Marie Glasheen, rev. Lorenzo Pericolo (Turnhout: Harvey Miller Publishers, 2015), 11-31 (pp. 12-13).

56 Victor Stoichita, 'Assemblage: How to Make a New Painting from an Old Image', in Stoichita, The Self-Aware Image, 103-25 (pp. 103-13). 
Cajés created this simultaneously narrative and iconic image by combining the normative elements of visionary experiences with the conventional form of frontal representation of cult images. The Virgin appears surrounded by angels and is placed upon a cloud, a clear sign of divine revelation that also worked as an instrument for distinguishing between the sacred and the earthly spheres. ${ }^{57}$ Instead, the material nature of Our Lady del Sagrario with the Christ Child is differentiated from the Virgin by rendering it through a hieratic attitude and frontal position, which was how the unspecified Marian sculpture was represented in the above-mentioned medieval codices in Parma and Madrid. As far as the drawing reveals, Cajés did not envision the Virgin and Child to be a faithful copy of the original sculpture but instead as being somehow animatedespecially the Child-and brought to life. In this context of co-presence of the Virgin and her image, the decision not to represent the recognisable features of the Sagrario, however, remains intriguing. ${ }^{58}$

Cajés was probably visually inspired by Valdivielso's sacramental play, which was performed on the final and most important day of the magnificent two-week festival that inaugurated the new Sagrario chapel in 1616. During the feasts, Our Lady del Sagrario was ceremoniously carried through the city, and its painted and sculpted representations were displayed on banners, in plays and on ephemeral decorations. Medals with its effigy were also made to be thrown to the crowds (Figure 9). ${ }^{59}$ The play was performed shortly after the procession of the Sagrario had taken place in the square between the archiepiscopal palace, the town hall and the cathedral. Philip III, the young Prince Philip (future Philip IV) and his French consort Isabel de Borbón, and the Spanish court attended the play and were seated by the windows of the cardinal's palace. ${ }^{60}$ At the end of the play, Valdivielso had envisaged an altar on the stage. There, 'una imajen de $\mathrm{N}$ [uest]ra S[eñor]a de bulto, que parezca a la del sagrario de Toledo, morena' had to be placed, so that 'quando baje N[uestr]a S[eñor]a, a dar la

57 Stoichita, El ojo místico, 81-84. Also see Guillaume Cassegrain, 'Le commentaire visionnaire: apparitions et persuasion dans la peinture italienne post-tridentine', Revue de l'art, 149 (2005), 5-12.

58 See a reverse situation in James Clifton, 'Mattia Preti's Madonna of Constantinople and a Marian Cult in Seventeenth-Century Naples', in Parthenope's Splendor: Art of the Golden Age in Naples, ed. Jeanne Chenault Porter \& Susan Scott Munshower (University Park, PA: Pennsylvania State University, 1993), 336-63.

59 Cloe Cavero de Carondelet, 'Art, Piety and Conflict in Early Modern Spain: The Religious and Artistic Patronage of Cardinal Bernardo de Sandoval between Toledo and Rome (1599-1618)', Doctoral dissertation (Florence: European University Institute, 2016), 255-62. Cécile Vincent-Cassy, 'Festejar a una imagen mariana y su envoltorio: las fiestas religiosas y cortesanas de la capilla del Sagrario de Toledo en 1616, del evento a los textos', in Visiones de un imperio en fiesta, ed. Inmaculada Rodríguez Moya \& Víctor Mínguez (Madrid: Fundación Carlos de Amberes, 2016), 145-62.

60 Herrera, Descripción de la Capilla, 42v, 68, 78v , 82-91. 
casulla al santo, la pueda abraçar'. In this version, the Virgin embraced the image not once, but twice. ${ }^{61}$

\section{An Altarpiece for Our Lady del Sagrario of Toledo}

The lack of information on the provenance of Eugenio Cajés' drawing before its arrival at the Biblioteca Nacional in Madrid is unfortunate. There are no archival documents or references to an altarpiece or a painting with a similar iconography known in early seventeenth century Spain. In 1906, Barcia asserted that the drawing had been intended as a draft for the pictorial decoration of the walls of the new Sagrario chapel, which had been commissioned by Cardinal-archbishop Bernardo de Sandoval y Rojas (r. 1599-1618) in 1614. ${ }^{62}$ This lavish chapel was completely covered with polychrome jaspers and marble, and the pictorial decoration had been given to Eugenio Cajés, Vicente Carducho and Carlo Saraceni. I contend that Cajés' drawing was not commissioned by Cardinal Sandoval but instead by a notable man or women connected with Toledo, most likely for the altarpiece of a private chapel. The absence of the finished altarpiece may suggest that the patron rejected Cajés' innovative invention for its potentially controversial depiction and chose a different subject matter for the altarpiece.

There are two main reasons why I contend that the drawing was not meant for the Sagrario chapel. Firstly, as has already been examined, the clear influence of Carlo Saraceni and Pedro Angelo's compositions and the probable connection with Valdivielso's sacramental play place the date of this preparatory drawing after 1616, and thus after completion of the pictorial decoration of the chapel. Nevertheless, even if one considers an earlier date for the drawing, there is no space in the chapel that might have accommodated it. ${ }^{63}$ The wall behind the high altarpiece was conceived as a barred opening through which to contemplate the relic collection. The walls were decorated with scenes from the life of the Virgin, and an earlier project only mentions the possible inclusion of the Epiphany and the Ascension of Christ. ${ }^{64}$ An alternative option is that the drawing was a design for the central panel of one of the four oratories, as a substitute for Saraceni's canvases. However, their measurements $(169 \times 137 \mathrm{~cm}$.) do not match the proportions of the drawing. If the drawing was commissioned by

61 Valdivielso, Auto famoso de la descensión, 18-19, 23. See also Cherry \& Mayo, 'The Fabric of Saintly Proof', 1339-52; Elena E. Marcello, 'De Valdivielso a Calderón: origen, pérdida y restauración de la Virgen del Sagrario', Criticón, 91 (2004), 79-91; Pedro Calderón de la Barca, La Virgen del Sagrario, su origen, perdida y restauración (Barcelona: Francisco Suriá, 1771).

62 Barcia, Catálogo, 26, No. 57.

63 As already noted in Angulo Íñiguez \& Pérez Sánchez, A Corpus, II, 18-19, No. 43.

64 Cavero de Carondelet, 'Art, Piety and Conflict', 116-36. 
Cardinal Sandoval himself for a different location, the reason why it was never executed may be because he died in 1618 .

Whatever purpose this composition was intended to serve, it is clear that it was commissioned by someone connected to Cardinal Sandoval's circle. Nevertheless, the lack of a comprehensive monograph on Cajés or his artistic production greatly hinders the pursuit of identifying potential patrons. A likely candidate might be the cleric Sebastián de Huerta (15761644), whose rising career began with his appointment as Cardinal Sandoval's secretary and continued with subsequent positions as secretary to the Inquisition and royal secretary. Recently identified in a portrait attributed to Velázquez, Huerta appears to have been a keen art patron. He was the patron of a magnificent chapel dedicated to the Immaculate Conception in the parish church of La Guardia, his home town. From 16311632, the chapel was decorated with oil and fresco paintings by Angelo Nardi. Earlier, in 1620, Huerta commissioned Eugenio Cajés to paint the central canvas of the Incarnation for his chapel in Santo Domingo el Antiguo in Toledo, and Nardi to paint two small-scale panels for the banco or lower platform of the altarpiece. ${ }^{65}$ It is possible that, either before or after this contract, Huerta also commissioned Cajés to create an altarpiece dedicated to Our Lady del Sagrario. If so, this image might have been envisioned together with lower scenes related to Toledo, and in a similar fashion to Cajés' small painting of the Virgin Giving the Chasuble to Saint Ildefonso in the Museo del Prado. ${ }^{66}$

\section{Conclusions: A Failed Iconography?}

Unlike the evident textual success of the episode of the Virgin's embrace of the Sagrario, Eugenio Cajés' drawing remains the only visual representation of an iconography that had-at best—very limited success in Spain. Even if the scarcity of visual or textual references to any similar iconography prevents us, at present, from drawing definitive conclusions in respect to this problem, it seems logical to further consider the possible reasons for the lack of images relating to an episode that was so strongly promoted in text. A possible explanation might be the doubts that Cajés' proposal potentially raised among the ecclesiastical elites who controlled

65 See Carmen Garrido, 'Velázquez y el Inquisidor', Ars Magazine, 17 (2013), 57-68; Angulo Íñiguez \& Pérez Sánchez, Historia de la pintura española: escuela madrileña del primer tercio del siglo XVII, 276, 228-29; José María Campoy, 'El secretario Huerta', Boletín de la Real Academia de Bellas Artes y Ciencias Históricas de Toledo, 16-17 (1923), 196-202. There is a preparatory drawing in the Museo del Prado, in red chalk and charcoal on yellow laid paper, for Cajés' Incarnation in Santo Domingo el Antiguo. However, it does not show significant similarities to the Sagrario drawing. See Alfonso E. Pérez Sánchez, Catálogo de dibujos. I. Dibujos españoles de los siglos XV-XVI-XVII (Madrid: Museo del Prado, 1972), 37 .

66 Oil on panel, 40 x $51 \mathrm{~cm}$. See Angulo Íñiguez \& Pérez Sánchez, Historia de la pintura española: escuela madrileña del primer tercio del siglo XVII, 247, No. 171. 
the production of sacred images. As has been outlined here, Cardinal Quiroga, García de Loaysa and Alonso de Villegas had reaffirmed the Church of Toledo's status as Spain's primatial see, by reconsecrating its medieval image through Mary's embrace. Despite the authority of these clerics, a number of scholars argued against the episode's veracity. However, the challenges to it remained a minority view, and accounts of the Virgin's embrace continued to be printed throughout the centuries. Why, then, is our drawing the only preserved image of this crucial moment in the history of the Church of Toledo?

In my view, Cajés' drawing raises problematic questions about the relationship between prototype and replica. The painter placed Our Lady del Sagrario in the centre of the composition and the centre of the narration. He enhanced its privileged status by depicting it with a distinctively iconic frontality and hieratism. In turn, the Virgin was represented gently leaning towards the Marian sculpture and paying special attention to the sculpted Child, thus placing the Virgin in an auxiliary position to the Our Lady del Sagrario. A painting that showed how the Virgin had chosen to honour one of her own portraits with her embrace, could indeed make the believer wonder if this replica was more powerful and worthy of veneration than the prototype itself. Thus, it can be argued that Cajés' drawing inadvertently challenged the sacred status of Marian images as replicas of the Virgin. The fact that the episode circulated widely and unproblematically in and beyond Spain in its text form suggests that there was a strong awareness of the instructive and moving power of images versus text in early modern Catholicism. In fact, the renewed veneration for Our Lady del Sagrario throughout the seventeenth century was mediated through unambiguous portraits of the sculpture itself. Painted and engraved replicas of the Sagrario in half length, lavishly dressed and jewelled, are still ubiquitous in churches and convents across the see of Toledo, such as the primatial cathedral (Figure 5), and the parish churches of Talavera de la Reina and La Guardia. In the Royal Convent of Las Descalzas Reales in Madrid, a space dedicated to piety and the political representation of Habsburg women, a painted image of the Sagrario can be viewed together with those of Our Lady de la Antigua and the Salus Populi Romani. Thus, the iconic portrait of Our Lady del Sagrario, which did not raise deeper questions about the relationship between prototype and replica, appears to have outlived the ambiguous iconography proposed by Eugenio Cajés. As Salazar de Mendoza wrote: 'Las pinturas son un muy fuerte argumento, y mayor, que el que se toma de la escritura, si van conformes con la tradicion, o co[n] las historias. Porque la pintura mueve y levanta mas el espiritu que la escritura' ${ }^{67}$

67 Salazar de Mendoza, El Glorioso Doctor San Il[d]efonso, 123. 
Captions:

\section{Figure 1}

Eugenio Cajés, The Virgin Embracing Our Lady del Sagrario (c. 1620). Drawing, red chalk and red wash on yellow laid paper, 297 x $192 \mathrm{~mm}$.

Biblioteca Nacional de España (Dib/15/1/9).

Reproduced by courtesy of the Biblioteca Nacional de España, Madrid.

\section{Figure 2}

Spanish artist, Saint Ildefonso Prays to the Enthroned Virgin (early $13^{\text {th }}$ century).

Miniature, gold and other colours, $18 \times 13 \mathrm{~cm}$.

Biblioteca Nacional de España (MSS/10087, fol. 8v).

Reproduced by courtesy of the Biblioteca Nacional de España, Madrid.

\section{Figure 3}

Spanish artist, The Virgin Giving the Chasuble to Saint Ildefonso (early $13^{\text {th }}$ century).

Miniature, gold and other colours, $18 \times 13 \mathrm{~cm}$.

Biblioteca Nacional de España (MSS/10087, fol. 110r).

Reproduced by courtesy of the Biblioteca Nacional de España, Madrid.

\section{Figure 4}

Our Lady del Sagrario (early $12^{\text {th }}$ century).

Sculpture, wood core, silver gilt vestment with cabochons, $114 \mathrm{~cm}$. Sagrario Chapel, Toledo Cathedral.

Photograph courtesy of Fernando Marías.

\section{Figure 5}

Spanish artist, Our Lady del Sagrario (early $17^{\text {th }}$ century).

Oil on canvas, $100 \times 126 \mathrm{~cm}$., Toledo Cathedral (ACT-BCT, 000-2).

Reproduced by courtesy of the Cabildo Catedral Primada, Toledo.

\section{Figure 6}

Attributed to Diego de Aguilar, The Virgin Giving the Chasuble to Saint

Ildefonso, with Saint John Evangelist (c. 1600).

Oil on canvas, 151 x $103 \mathrm{~cm}$., Museo de Santa Cruz (CE18251).

Reproduced by courtesy of the Museo de Santa Cruz, Toledo.

Photograph courtesy of Luis Morales Rodríguez.

\section{Figure 7}

Carlo Saraceni, The Virgin Giving the Chasuble to Saint Ildefonso (1614).

Oil on canvas, $169 \times 137 \mathrm{~cm}$., Sagrario Chapel, Toledo Cathedral. 
Reproduced by courtesy of the Cabildo Catedral Primada, Toledo.

\section{Figure 8}

Pedro Angelo, The Virgin Giving the Chasuble to Saint Ildefonso (c. 1616).

Print in Francisco Portocarrero, Libro de la Descension de Nuestra Señora a la Santa Yglesia de Toledo (Madrid: Luis Sánchez, 1616).

Biblioteca Nacional de España (R/10932).

Reproduced by courtesy of the Biblioteca Nacional de España, Madrid.

\section{Figure 9}

Our Lady del Sagrario (1616).

Lead medal, diameter $40 \mathrm{~mm}$.

Museo Arqueológico Nacional (1993_80_431_3-ID002).

Reproduced by courtesy of the Museo Arqueológico Nacional, Madrid. Photograph courtesy of Ángel Martínez Leivas. 